\title{
FAKTOR RISIKO KEJADIAN STUNTING PADA BALITA USIA 12 BULAN DI DESA PURWOKERTO KECAMATAN PATEBON, KABUPATEN KENDAL
}

\author{
Friska Meilyasari, Muflihah Isnawati ${ }^{*}$ \\ Program Studi Ilmu Gizi Fakultas Kedokteran Universitas Diponegoro \\ Jl.Dr.Sutomo No.18, Semarang, Telp (024) 8453708, Email : gizifk@undip.ac.id
}

\begin{abstract}
ABSTRAK
Latar Belakang: Prevalensi stunting pada balita di Kabupaten Kendal mencapai $42 \%$ dengan kejadian tertinggi di Kecamatan Patebon (38,7\%). Stunting dapat meningkatkan risiko terjadinya kesakitan, kematian, gangguan perkembangan motorik dan penurunan produktivitas di masa mendatang. Penelitian ini bertujuan untuk menganalisis faktor risiko kejadian stunting balita usia 12 bulan di Desa Purwokerto Kecamatan Patebon, Kabupaten Kendal.

Metode: Penelitian observasional dengan rancangan kasus kontrol. Sampel dipilih dengan teknik consecutive sampling dengan jumlah sampel 24 subjek untuk masing-masing kelompok. Data panjang badan lahir, berat badan lahir, usia kehamilan, lama ASI eksklusif, usia pengenalan MP-ASI dan skor pemberian MP-ASI diperoleh melalui wawancara menggunakan kuesioner. Food recall $2 \times 24$ jam dilakukan untuk mengidentifikasi jenis MP-ASI yang diberikan dan kebiasaan makan balita. Analisis bivariat dengan uji Chi Square atau Fisher Exact.

Hasil: Hasil analisis bivariat menunjukkan faktor risiko yang berpengaruh terhadap kejadian stunting pada balita usia 12 bulan di Desa Purwokerto adalah panjang badan lahir rendah $(O R=16,43 ; p=0,002)$, prematuritas $(O R=11,5 ; p=0,023)$ dan usia makan pertama $(O R=4,24 ; p=0,040)$. Berat badan lahir rendah $(O R=3,28$; $p=0,609)$, lama pemberian ASI eksklusif (OR=2,06; $p=0,303)$, dan skor MP-ASI $(O R=1,41 ; p=0,77)$ bukan merupakan faktor risiko kejadian stunting pada penelitian ini.

Simpulan: Faktor risiko kejadian stunting pada balita usia 12 bulan adalah panjang badan lahir rendah (pendek), prematuritas dan usia makan pertama.
\end{abstract}

Kata Kunci: stunting; faktor risiko; balita usia 12 bulan; malnutrisi

\begin{abstract}
Background: Prevalence of stunting among under five children in Kendal district was $42 \%$ with highest incident in Patebon Subdistrict (38,7\%). Stunting assiciated with an increased risk of morbidity, mortality, impaired motor development and low productivity in the future. The study aimed to analyze the risk factors of stunting among 12 month old children at Purwokerto Village Patebon Subdistrict in Kendal District.

Methods: An observasional study with case control design. The samples were selected by consecutive sampling with number of samples were 24 subjects for each groups. Information on birth length and weight, gestational age, exclusive breastfeeding period, first complementary feeding time and complementary feeding score were obtain through interviews using questionnaires. The $2 \times 24$ hours dietary assessment was conducted to identify the type of complementary foods given and the eating habits. Bivariate analyzed with Chi Square or Fisher Exact test.

Results: The bivariate analysis showed that risk factors of stunting on 12 month old children at Purwokerto village were low birth length $(O R=16,43 ; p=0,002)$, prematurity $(O R=11,5 ; p=0,023)$ and first complementary feeding time $(O R=4,24 ; p=0,040)$. Low birth weight $(O R=3,28 ; p=0,609)$, exclusive breastfeeding period $(O R=2,06$; $p=0,303)$, and complementary feeding score $(O R=1,41 ; p=0,77)$ were not risk factors of stunting, in this study.

Conclusion: Risk factors of stunting among 12 month old children were low birth length, prematurity and first complementary feeding time.
\end{abstract}

Keywords: stunting; risk factors; children 12 month; malnutriton

\section{PENDAHULUAN}

Upaya perbaikan status gizi balita di Indonesia dalam beberapa tahun terakhir sudah mengalami peningkatan. Hasil Riset Kesehatan Dasar tahun 2010, prevalensi gizi kurang dan buruk telah mengalami penurunan dari $18,4 \%$ tahun 2007 menjadi 17,9\% tahun 2010, sedangkan prevalensi balita pendek terdiri dari sangat pendek $18,5 \%$ dan pendek $17,1 \%$. Penurunan prevalensi terjadi pada balita pendek dari $18,0 \%$ menjadi
$17,1 \%$ dan balita sangat pendek dari $18,8 \%$ menjadi $18,5 \%{ }^{1}$ Akan tetapi, tidak demikian yang terjadi di Kabupaten Kendal. Prevalensi stunting di Kabupaten Kendal mencapai $42 \%$ dengan kejadian tertinggi di Kecamatan Patebon $(38,7 \%){ }^{2}$ Jika hal ini tidak segera ditanggulangi maka dapat menyebabkan gangguan perkembangan fungsi kognitif dan psikomotor, penurunan kemampuan intelektual dan produksi kerja serta peningkatan kelahiran bayi dengan berat badan lahir rendah 
(BBLR) dan risiko penyakit degeneratif di masa mendatang. ${ }^{3,4}$

Stunting atau pendek merupakan salah satu indikator status gizi kronis yang menggambarkan terhambatnya pertumbuhan karena malnutrisi jangka panjang. Menurut Keputusan Menteri Kesehatan Republik Indonesia Nomor 1995/MENKES/SK/XII/2010 tentang Standar Antropometri Penilaian Status Gizi Anak, pendek dan sangat pendek adalah status gizi yang didasarkan pada indeks panjang badan menurut umur $(\mathrm{PB} / \mathrm{U})$ atau tinggi badan menurut umur (TB/U) yang merupakan padanan istilah stunted (pendek) dan severely stunted (sangat pendek). Zscore untuk kategori pendek adalah -3 SD sampai dengan <-2 SD dan sangat pendek adalah <-3 SD. ${ }^{5}$

Beberapa faktor yang mempengaruhi kejadian stunting antara lain berat badan lahir, panjang badan lahir, usia kehamilan dan pola asuh ibu. Defisiensi energi kronis atau anemia selama kehamilan dapat menyebabkan ibu melahirkan bayi dengan berat lahir rendah. ${ }^{6}$ Tingginya angka BBLR diperkirakan menjadi penyebab tingginya kejadian stunting di Indonesia. Penelitian di Malawi dengan desain kohort menunjukkan bahwa berat badan lahir rendah merupakan prediktor terkuat kejadian stunting pada balita usia 12 bulan. ${ }^{7}$ Pertumbuhan linier bayi berat lahir rendah dengan usia kehamilan $\geq 37$ minggu (disebut bayi IUGR) lebih lambat daripada bayi normal. Namun, pertumbuhan bayi BBLR prematur (usia kehamilan <37 minggu) dalam lingkungan yang mendukung akan tumbuh lebih baik daripada bayi IUGR, jika berat lahir bayi sesuai dengan usia kehamilan. ${ }^{8}$ Penelitian di Tangerang dengan desian kohort menunjukkan bayi yang lahir prematur memiliki risiko 2 kali lebih besar dibanding bayi yang lahir normal untuk menjadi stunting pada usia 6-12 bulan. ${ }^{9}$

Rendahnya asupan gizi pada bayi yang lahir normal juga berkontribusi terhadap stunting. ${ }^{10}$ Stunting sangat erat kaitannya dengan pola pemberian makanan terutama pada 2 tahun pertama kehidupan, yaitu ASI dan MP-ASI. Pola pemberian makanan dapat mempengaruhi kualitas konsumsi makanan balita, sehingga dapat mempengaruhi status gizi balita. ${ }^{11}$ Pemberian ASI yang kurang dari 6 bulan dan MP-ASI terlalu dini dapat meningkatkan risiko stunting karena saluran pencernaan bayi belum sempurna sehingga lebih mudah terkena penyakit infeksi seperti diare dan ISPA. $^{12}$ Hasil penelitian dari mengolah data Riskesdas 2007 didapatkan defisit energi pada bayi 6-11 bulan sebesar 210 kkal sedangkan anak baduta 12-23 bulan sebesar $300 \mathrm{kkal}$, sementara defisit protein pada bayi 6-11 bulan sebesar $5 \mathrm{gr}$ dan pada anak 12-23 bulan sebesar 7,5 gr. ${ }^{13}$

Berdasarkan uraian di atas, peneliti tertarik untuk mengetahui faktor-faktor risiko kejadian stunting pada balita usia 12 bulan di Desa Purwokerto Kecamatan Patebon, Kabupaten Kendal. Tujuan penelitian ini adalah untuk menganalisis faktor risiko kejadian stunting pada balita usia 12 bulan.

\section{METODE PENELITIAN}

Penelitian ini dilaksanakan di Desa Purwokerto Kecamatan Patebon Kabupaten Kendal pada bulan November-Desember 2013. Jenis penelitian observasional dalam bidang gizi masyarakat dengan rancangan penelitian case control. Populasi dalam penelitian ini adalah seluruh balita usia 12 bulan yang berada di Desa Purwokerto. Besar subjek minimal yang diperlukan dihitung berdasarkan rumus besar subjek pada studi kasus kontrol berpasangan dengan tingkat kemaknaan $95 \% \quad(\mathrm{Z} \alpha=1,96)$, kekuatan $90 \%$ $(Z \beta=1,282), O R=4,2$ sehingga diperoleh subjek minimal sebanyak 24 orang dengan perbandingan kasus dan kontrol 1:1. Kasus adalah balita stunting usia 12 bulan dengan indeks z-score $\mathrm{PB} / \mathrm{U}<-2 \mathrm{SD}$ dan kontrol adalah balita usia 12 bulan dengan indeks z-score $\mathrm{PB} / \mathrm{U}$-2 $\mathrm{SD}$ sampai $+2 \mathrm{SD}$. Responden dalam penelitian ini adalah ibu balita yang terpilih menjadi subjek penelitian. Pemilihan subjek penelitian dilakukan dengan menggunakan teknik consecutive sampling berdasarkan kriteria inklusi yaitu anak usia 12 bulan, ibu bersedia menjadi responden, nilai z-score untuk indeks $\mathrm{PB} / \mathrm{U}<-2 \mathrm{SD}$ (kelompok kasus) dan z-score untuk indeks PB/U -2 SD s/d +2SD (kelompok kontrol).

Variabel terikat dalam penelitian ini adalah status balita gizi stunting, sedangkan variabel bebas terdiri dari panjang badan lahir, berat badan lahir, usia kehamilan, lama pemberian ASI eksklusif, usia pengenalan MP-ASI dan pemberian MP-ASI. Data yang dikumpulkan antara lain data identitas subjek, panjang badan lahir yang dikategorikan normal $(\geq 48 \mathrm{~cm})$ dan pendek $(<48$ $\mathrm{cm})^{14}$, berat badan lahir yang dikategorikan normal $(\geq 2500 \mathrm{~g})$ dan rendah $(<2500 \mathrm{~g})^{14}$, usia kehamilan yang dikategorikan cukup bulan ( $\geq 37$ minggu) dan prematur $(<37 \text { minggu })^{14}$, lama ASI eksklusif yang dikategorikan ASI eksklusif dan non-ASI eksklusif ${ }^{15}$, usia pengenalan MP-ASI yang dikategorikan $<6$ bulan dan $\geq 6$ bulan ${ }^{16}$, pemberian MP-ASI berdasarkan total skor pertanyaan yang diubah ke dalam skor $\mathrm{T}$ yang 
kemudian dikategorikan baik jika skor $\mathrm{T} \geq$ mean dan kurang jika skor $\mathrm{T}<$ mean $^{17}$. Instrumen yang digunakan adalah kuesioner. Data asupan makan diperoleh melalui food recall 2x24 jam. Hasil yang sudah diperoleh kemudian diolah menggunakan program nutrisurvey, lalu dihitung rerata konsumsinya perhari.

Analisis data dengan program SPSS. Analisis univariat untuk mendeskripsikan setiap variabel penelitian. Analisis bivariat untuk melihat hubungan variabel dan besar risiko (OR) antara berat badan lahir, panjang badan lahir, usia kehamilan, lama ASI eksklusif, usia pengenalan MP-ASI dan pemberian MP-ASI dengan kejadian stunting pada anak usia 12 bulan. Analisis bivariat menggunakan uji Chi-Square dengan $\alpha 0,05$ dan uji Fisher Exact. ${ }^{18}$

\section{HASIL PENELITIAN \\ 1. Karakteristik Subjek}

Jumlah sampel dalam penelitian ini sebanyak 48 balita yang dibagi menjadi 24 balita kelompok kasus dan 24 kelompok kontrol. Jumlah subjek perempuan lebih banyak baik pada kelompok kasus $(54,2 \%)$ maupun kelompok kontrol $(58,3 \%)$. Rerata $z$-score pada kelompok kasus adalah -2,68 SD sedangkan rerata $z$-score untuk kelompok kontrol -0,45 SD.

Tabel 1. Deskripsi Variabel Mean \pm SD

\begin{tabular}{|c|c|c|c|c|c|c|}
\hline \multirow[b]{2}{*}{ Karakteristik } & \multicolumn{3}{|c|}{ Kasus } & \multicolumn{3}{|c|}{ Kontrol } \\
\hline & Mean \pm SD & Min & Maks & Mean \pm SD & Min & $\begin{array}{c}\text { Mak } \\
\text { s }\end{array}$ \\
\hline $\begin{array}{l}\text { Panjang badan } \\
\text { lahir }(\mathrm{cm})\end{array}$ & $47,3 \pm 1,66$ & 43 & 50 & $49 \pm 1,46$ & 47 & 52 \\
\hline $\begin{array}{l}\text { Berat badan lahir } \\
\text { (g) }\end{array}$ & $\begin{array}{l}2850 \pm \\
359,95\end{array}$ & 2000 & 3500 & $\begin{array}{l}3152 \pm \\
430,24\end{array}$ & 2400 & 4100 \\
\hline $\begin{array}{l}\text { Usia kehamilan } \\
(\mathrm{minggu})\end{array}$ & $36,6 \pm 1,28$ & 32 & 39 & $37 \pm 0,29$ & 36 & 38 \\
\hline $\begin{array}{l}\text { Lama pemberian } \\
\text { ASI eksklusif (bln) }\end{array}$ & $2,2 \pm 2,84$ & 0 & 8 & $3,67 \pm 2,41$ & 0 & 6 \\
\hline $\begin{array}{l}\text { Usia makan } \\
\text { pertama (bln) }\end{array}$ & $4,3 \pm 2,06$ & 0 & 8 & $5,5 \pm 1,47$ & 2 & 8 \\
\hline Skor MP-ASI & $189 \pm 39$ & 113,6 & 253,6 & $191 \pm 31,24$ & 143,6 & $\begin{array}{l}263 \\
6\end{array}$ \\
\hline
\end{tabular}

Tabel 1 menunjukkan bahwa sebagian besar subjek baik pada kelompok kasus maupun kelompok kontrol memiliki berat badan lahir yang normal. Rerata lama pemberian ASI eksklusif pada kelompok kasus dan kelompok kontrol kurang dari 6 bulan. Bahkan pada kelompok kasus terdapat praktek pemberian ASI saja tanpa makanan pendamping sampai usia 8 bulan.

Penelitian ini juga menunjukkan bahwa terdapat praktek pemberian makan pertama yang terlalu dini. Sebagian besar subjek diberikan bubur instan untuk makanan pertama dan susu formula untuk minuman pertama. Selain itu juga ditemukan praktek pemberian makanan yang kurang tepat, diantaranya pemberian nasi tim sebagai makanan pertama pada kelompok kontrol dan pemberian susu sapi sebagai minuman pertama pada kelompok kasus.

\section{Data Food Recall 2x24 Jam}

Tabel 2. Persentase Energi dari Asupan Karbohidrat, Asupan Protein, dan Asupan Lemak pada anak stunting dan normal

\begin{tabular}{lcccccc}
\hline \multirow{2}{*}{ Karakteristik } & \multicolumn{3}{c}{ Kasus } & \multicolumn{3}{c}{ Kontrol } \\
\cline { 2 - 7 } & Mean \pm SD & Min & Maks & Mean \pm SD & Min & Maks \\
\hline Asupan & $68,3 \pm 11,6$ & 51,0 & 89,7 & $69,8 \pm 12,4$ & 53,7 & 90,8 \\
Karbohidrat & & & & & & \\
\hline Asupan Protein & $12,4 \pm 1,6$ & 7,9 & 14,6 & $11,9 \pm 1,7$ & 8,9 & 14,7 \\
\hline Asupan Lemak & $19,2 \pm 10,2$ & 1,4 & 34,3 & $18,3 \pm 11,9$ & 1,3 & 33,38 \\
\hline
\end{tabular}


Berdasarkan tabel 2, diketahui bahwa makanan pendamping hanya mampu memenuhi $60 \%$ dari total kebutuhan energi harian. Rerata asupan harian ini masih sangat rendah jika dibandingkan rekomendasi WHO. Komposisi makanan pendamping terus berubah seiring bertambahnya usia balita dimana karbohidrat sebagai kontributor energi yang utama.

\section{Analisis Bivariat}

Tabel 3. Tabel silang faktor BB lahir, PB lahir, lama pemberian ASI eksklusif, usia makan pertama dan skor MP-ASI dengan kejadian stunting

\begin{tabular}{|c|c|c|c|c|c|c|}
\hline & \multicolumn{4}{|c|}{$\begin{array}{c}\text { Status gizi berdasarkan } z \text {-score } \\
\mathrm{PB} / \mathrm{U}\end{array}$} & \multirow[t]{3}{*}{$\mathbf{P}$} & \multirow[t]{3}{*}{ OR (CI 95\%) } \\
\hline & \multicolumn{2}{|c|}{ Kasus } & \multicolumn{2}{|c|}{ Kontrol } & & \\
\hline & $\mathbf{n}$ & $\%$ & $\mathbf{N}$ & $\%$ & & \\
\hline \multicolumn{7}{|c|}{ Panjang badan lahiı } \\
\hline Pendek & 10 & 41,7 & 1 & 4,2 & 0,002 & 16,43 \\
\hline Normal & 14 & 58,3 & 23 & 95,8 & & $(1,89-142,5)$ \\
\hline \multicolumn{7}{|c|}{ Berat badan lahir } \\
\hline Rendah & 3 & 12,5 & 1 & 4,2 & 0,609 & 3,28 \\
\hline Normal & 21 & 87,5 & 23 & 95,8 & & $(0,33-1,21)$ \\
\hline \multicolumn{7}{|c|}{ Usia kehamilan } \\
\hline Prematur & 8 & 33,3 & 1 & 4,2 & 0,023 & 11,5 \\
\hline Normal & 16 & 66,7 & 23 & 95,8 & & $\begin{array}{l}(1,31- \\
101,2)\end{array}$ \\
\hline \multicolumn{7}{|c|}{$\begin{array}{l}\text { Lama pemberian ASI } \\
\text { eksklusif }\end{array}$} \\
\hline$<$ atau $>6$ bln & 20 & 83,3 & 17 & 70,8 & 0,303 & 2,06 \\
\hline$=6 \mathrm{bln}$ & 4 & 16,7 & 7 & 29,2 & & $(0,51-8,25)$ \\
\hline \multicolumn{7}{|c|}{ Usia makan pertam; } \\
\hline$<6$ bln & 14 & 58,3 & 6 & 25 & 0,040 & 4,24 \\
\hline$\geq 6 \mathrm{bln}$ & 10 & 41,7 & 18 & 75 & & $(0,70-0,81)$ \\
\hline \multicolumn{7}{|l|}{ Skor MP-ASI } \\
\hline Kurang & 11 & 45,8 & 9 & 37,5 & 0,77 & 1,41 \\
\hline Baik & 13 & 54,2 & 15 & 62,5 & & $(0,44-4,46)$ \\
\hline
\end{tabular}

Tabel 3 menunjukkan analisis bivariat menggunakan uji chi-square dan uji modifikasi Fisher, variabel yang terbukti bermakna sebagai faktor risiko stunting adalah panjang badan lahir rendah (pendek), usia kehamilan dan usia makan pertama dengan nilai $p$ value $<0,05$. Diantara ketiga variabel tersebut, panjang badan lahir memiliki pengaruh yang paling besar terhadap kejadian stunting dengan nilai $\mathrm{OR}=16,43$. Variabel yang tidak terbukti sebagai faktor risiko stunting adalah berat badan lahir, lama pemberian ASI eksklusif dan skor MP-ASI dengan $p$ value $>0,05$.

\section{PEMBAHASAN PENELITIAN}

Pada penelitian ini, panjang badan lahir merupakan faktor risiko stunting balita usia 12 tahun. Hasil penelitian ini sejalan dengan penelitian di Tangerang yang menyebutkan bahwa anak dengan panjang badan lahir kurang dari 48 $\mathrm{cm}$ memiliki risiko untuk mengalami stunting pada usia 6-12 bulan sebesar 2,4 kali lebih besar dibanding anak yang lahir dengan panjang badan lahir normal. Namun, anak tersebut dapat mencapai tinggi badan yang normal pada usia 3-4 tahun apabila asupan gizinya tercukupi. ${ }^{9}$ Bayi yang lahir dengan panjang badan lahir pendek menunjukkan asupan gizi ibu yang kurang selama masa kehamilan, sehingga pertumbuhan janin di dalam kandungan tidak optimal. ${ }^{10}$ Asupan gizi yang baik penting untuk menunjang pertumbuhan anak yang lahir dengan panjang badan lahir pendek agar mendapatkan panjang badan yang normal seiring bertambahnya usia. ${ }^{19}$

Hasil penelitian ini menunjukkan bahwa berat badan lahir balita bukan merupakan faktor risiko stunting $(\mathrm{p}=0,609)$. Sebagian besar subjek baik pada kelompok kasus $(87,5 \%)$ maupun kelompok kontrol $(95,8 \%)$ memiliki berat badan lahir yang normal. Hasil ini berbeda dengan penelitian di Libya yang menyimpulkan bahwa 
riwayat malnutrisi, dalam hal ini diperlihatkan oleh berat badan lahir rendah mempengaruhi kejadian stunting pada anak usia 1-2 tahun $(\mathrm{p}<0.05$, $\mathrm{OR}=1.58) .{ }^{20} \mathrm{Hal}$ ini dikarenakan tingginya pengaruh berat badan lahir terhadap kejadian stunting terjadi pada usia 6 bulan awal, kemudian menurun hingga usia 24 bulan. Jika pada 6 bulan awal balita dapat mengejar pertumbuhan, maka besar kemungkinan balita tersebut dapat tumbuh secara normal. ${ }^{21}$ Besar risiko bayi yang lahir dengan berat badan lahir rendah untuk menjadi stunting pada usia 6-12 bulan adalah 3,6 kali dibanding bayi yang lahir dengan berat badan lahir normal. ${ }^{9}$ Bayi dengan riwayat berat badan lahir rendah menunjukkan terjadinya retardasi pertumbuhan di dalam uterus baik akut maupun kronis dan lebih berisiko mengalami gangguan pertumbuhan di masa anak-anak karena lebih rentan terhadap penyakit infeksi, seperti diare. ${ }^{6,10}$ Walaupun secara statistik hasil penelitian ini menyebutkan bahwa berat badan lahir rendah bukan merupakan faktor risiko stunting, tetapi bayi yang lahir dengan berat badan lahir rendah cukup mempengaruhi kejadian stunting $(\mathrm{OR}=3,28)$. Oleh karena itu, orang tua yang memiliki anak dengan berat badan lahir rendah harus lebih sadar akan kejadian stunting.

Sebuah penelitian di Tangerang menunjukkan bahwa bayi yang lahir prematur berisiko 2 kali pada usia 6-12 bulan untuk mengalami stunting. ${ }^{9}$ Hasil penelitian ini menunjukkan usia kehamilan merupakan faktor risiko kejadian stunting balita usia 12 bulan. Pertumbuhan pada bayi prematur mengalami keterlambatan dikarenakan usia kehamilan yang singkat dan adanya retardasi pertumbuhan linear di dalam kandungan. Bayi yang lahir cukup bulan apabila asupan gizinya kurang juga akan mengalami growth faltering. Hal ini akan bertambah berat jika ditambah dengan paparan penyakit infeksi. ${ }^{8}$ Sebaliknya, bayi prematur yang mengalami growth faltering jika diberikan dukungan asupan gizi yang adekuat maka pola pertumbuhan normal dapat terkejar (catch up). ${ }^{20}$

Pada penelitian ini lama pemberian ASI eksklusif bukan merupakan faktor risiko stunting balita usia 12 bulan. Penelitian ini sejalan dengan penelitian yang dilakukan di Tangerang dan Semarang, dimana lama pemberian ASI eksklusif bukan merupakan risiko kejadian stunting. Bayi yang tidak diberikan ASI eksklusif selama 6 bulan berisiko 1,3 kali lebih besar mengalami stunting pada usia 6-12 bulan. Fungsi ASI sebagai antiinfeksi dapat mempengaruhi perubahan status stunting pada balita. ${ }^{9}$ Lama pemberian ASI yang kurang dan pemberian makanan atau susu formula yang terlalu dini dapat meningkatkan risiko stunting karena bayi cenderung lebih mudah terkena penyakit infeksi seperti diare dan ISPA. ${ }^{12,22}$ Hasil wawancara yang mendalam dengan ibu balita, diketahui banyak ibu balita memberikan ASI dikombinasikan dengan susu formula. Alasan yang paling banyak dikemukakan oleh ibu balita adalah ASI tidak lancar, selain itu ibu bekerja dan bayi masih rewel meskipun sudah diberi ASI. Mudahnya mendapatkan susu formula membuat ibu kurang berusaha untuk meningkatkan produksi ASI-nya. Menyusui sekaligus memberikan susu formula memang dapat memenuhi kebutuhan zat gizi bayi sehingga tidak terganggu pertumbuhannya, tetapi susu formula tidak mengandung zat antibodi sebaik ASI sehingga bayi lebih rawan terkena penyakit. Pada penelitian ini, lama pemberian ASI eksklusif bukan merupakan faktor risiko stunting dikarenakan ibu subjek mengkombinasikan ASI dengan susu formula sehingga kebutuhan zat gizi balita tetap terpenuhi dan tidak mengganggu pertumbuhan. Selain itu, data yang diambil merupakan data sekunder sehingga ada kemungkinan data tidak akurat.

Pada penelitian ini juga ditemukan 1 balita kelompok kasus yang menerima ASI saja tanpa MP-ASI hingga usia 8 bulan. Pemberian ASI saja melebihi 6 bulan menyebabkan bayi tidak dapat melatih saluran pencernaanya untuk menerima makanan lain selain makanan cair sehingga dapat menyebabkan growth faltering karena defisisensi zat gizi. Penelitian di Senegal menyimpulkan bahwa pemberian ASI eksklusif selama lebih dari 2 tahun berhubungan dengan prevalensi stunting yang lebih tinggi. ${ }^{22}$ Walaupun secara statistik lama pemberian ASI eksklusif bukan merupakan faktor risiko kejadian stunting pada penelitian ini, tetapi balita yang tidak diberikan ASI eksklusif memiliki risiko 2,06 kali lebih besar menjadi stunting dibanding yang mendapat ASI eksklusif.

Menginjak usia 6 bulan, pemberian ASI saja tidak cukup memenuhi kebutuhan gizi bayi maka diperlukan sumber zat gizi tambahan dari makanan pendamping ASI. ${ }^{16}$ MP-ASI yang tepat dan baik merupakan makanan yang dapat memenuhi kebutuhan gizi sehingga bayi dan anak dapat tumbuh kembang secara optimal. MP-ASI diberikan secara bertahap sesuai dengan usia anak, disamping itu pemberian ASI terus dilanjutkan sebagai sumber zat gizi dan antibodi sampai anak mencapai usia 2 tahun atau lebih. Pada penelitian ini diketahui usia makan pertama merupakan faktor 
risiko stunting balita usia 12 bulan. Penelitian di Medan di Kecamatan Pandan Kabupaten Tapanuli Tengah ditemukan bahwa sebanyak $89,8 \%$ responden memberikan MP-ASI dini pada bayi usia $<6$ bulan. ${ }^{23}$ Pemberian MP-ASI dini pada bayi usia kurang dari 6 bulan menjadi salah satu penyebab gagalnya seorang ibu memberikan ASI eksklusif. Penelitian lain di India menunjukkan bahwa pemberian MP-ASI pada usia dini yaitu pada usia 0 sampai 2 bulan dapat meningkatkan risiko stunting pada balita usia 2-4 tahun. ${ }^{24}$ Pemberian MP-ASI terlalu dini meningkatkan risiko penyakit infeksi seperti diare karena MPASI yang diberikan tidak sebersih dan mudah dicerna seperti ASI. Diare dihubungkan dengan gagal tumbuh karena terjadi malabsorbsi zat gizi selama diare. Jika zat gizi seperti zink dan tembaga serta air yang hilang selama diare tidak diganti, maka akan timbul dehidrasi parah, malnutrisi, gagal tumbuh bahkan kematian. ${ }^{25}$ Selain pemberian MP-ASI yang terlalu dini, terlambatnya memberikan MP-ASI juga menyebabkan pertumbuhan dan perkembangan balita menjadi terhambat karena kebutuhan gizi balita tidak tercukupi. Pada penelitian ini diketahui terdapat 2 anak pada kelompok kasus dan 1 anak pada kelompok kontrol yang mendapat MP-ASI pertama pada usia lebih dari 6 bulan.

Adanya gangguan pertumbuhan linier pada balita dikarenakan kualitas dan kuantitas MP-ASI yang rendah. ${ }^{26}$ Peran ibu sangat penting dalam menentukan baiknya kualitas dan kuantitas MPASI yang diberikan. Rendahnya kualitas dan kuantitas MP-ASI yang diberikan ditunjukkan dengan data asupan makan dari food recall $2 \times 24$ jam dimana total asupan energi dari MP-ASI hanya dapat memenuhi $60 \%$ dari total energi harian. Hal ini menunjukkan bahwa MP-ASI yang diberikan belum dapat mencukupi kebutuhan sehari-hari balita. Rendahnya konsumsi energi pada balita stunting kemungkinan disebabkan oleh beberapa faktor seperti frekuensi dan jumlah pemberian makanan, densitas energi yang rendah, nafsu makan berkurang dan adanya penyakit infeksi. ${ }^{27}$ Kontribusi karbohidrat yang tinggi dari MP-ASI disebabkan oleh makanan yang dikonsumsi balita terutama diproduksi secara lokal, seperti jagung, singkong dan ubi jalar. Karakteristik MP-ASI bisa menjadi salah satu faktor penting yang berhubungan dengan kekurangan energi protein pada balita. Pada usia $6-8$ bulan sebaiknya bayi diperkenalkan pada makanan lunak lebih dahulu seperti sereal fortifikasi besi, puree sayuran dan biskuit bayi. ${ }^{28,29}$
Pada penelitian ini diketahui praktek pemberian makanan dan minuman pertama yang kurang tepat yaitu pemberian nasi tim lunak dan susu sapi. Penelitian oleh Barrens et al melaporkan bahwa pemberian MP-ASI berupa nasi lunak pada usia dini berhubungan dengan stunting pada usia 6 bulan. ${ }^{30}$ Nasi tim tidak dianjurkan sebagai makanan pertama karena kemampuan mengunyah bayi belum sempurna sehingga nasi tim sulit dikonsumsi dalam jumlah yang cukup untuk memenuhi kebutuhan energi. Susu sapi memiliki kandungan zat besi, asam linoleat, vitamin $\mathrm{C}$ dan vitamin $\mathrm{E}$ yang rendah tetapi kandungan natrium, kalium, kalsium dan proteinnya tinggi. Asupan kalsium yang tinggi dan vitamin $\mathrm{C}$ yang rendah dapat menghambat absorbsi zat besi. Selain itu, kandungan protein yang tinggi juga dapat memperberat kerja ginjal bayi. Susu sapi dapat menyebabkan perdarahan pada saluran cerna jika diberikan pada bayi dengan usia kurang dari 6 bulan. ${ }^{28,29}$

\section{SIMPULAN}

Faktor risiko kejadian stunting pada anak usia 12 bulan di Desa Purwokerto Kecamatan Patebon Kabupaten Kendal adalah panjang badan lahir rendah, usia kehamilan dan usia makan pertama.

\section{KETERBATASAN PENELITIAN}

Pengumpulan data asupan makan menggunakan formulir food recall yang seharusnya $3 \times 24$ jam, tetapi dikarenakan ibu subjek banyak yang lupa sehingga hanya dilakukan 2x24 jam.

\section{SARAN}

Perlu penelitian lanjutan untuk menganalisis kontribusi asupan energi dan zat gizi dari MP-ASI dan menganalisis mutu gizi MP-ASI yang diberikan untuk dijadikan dasar penyusunan menu makanan pada bayi dan balita. Selain itu juga perlu pemberian pengetahuan kepada masyarakat mengenai pentingnya pemberian MP-ASI terkait waktu dan kualitas melalui kegiatan konseling di puskesmas dan masyarakat oleh petugas kesehatan.

\section{DAFTAR PUSTAKA}

1. Badan Penelitian Dan Pengembangan Kesehatan Kementerian Kesehatan RI. Riset kesehatan dasar 2010: Laporan Nasional. 2010.

2. Badan Penelitian dan Pengembangan Kesehatan Departemen Kesehatan RI. Riset Kesehatan Dasar 2007: Laporan Provinsi Jawa Tengah. 2008.

3. Milman A, Frongillo EA, Onis MD, Hwang JY. Differential Improvement among Countries in Child Stunting is Associated with Long-Term 
Development and Specific Interventions. The Journal of Nutrition. 2005.

4. Sari M, Pee Sd, Bloem MW, Sun K, ThorneLyman AL, MoenchPfanner R, et al. Higher household expenditure on animal-source and nongrain foods lowers the risk of stunting among children 0-59 months old in Indonesia: implications of rising food prices. The Journal of Nutrition. 2010; 140:196-200.

5. Kementerian kesehatan RI. Keputusan menteri kesehatan RI No. 1995/Menkes/SK/XII/2010 tentang Standar Antropometri Penilaian Status Gizi Anak. 2011.

6. Keefe CJL, Couch SC, Philipson EH. Handbook of Nutrition and Pregnancy. USA: Humana Press; 2008. p. 27-28.

7. Espo M., T, Kulmala, K. Maleta, T. Cullinan, M-L Salin, P Ashorn. 2002. Determinants of linear growth and predictors of severe stunting during infancy in rural Malawi. Acta Paediatr, 91 : 13641370

8. Kusharisupeni. Growth Faltering pada Bayi di Kabupaten Indramayu Jawa Barat. Makara Kesehatan. 2002; 6: 1-5.

9. Rahayu LS, Sofyaningsih M. Pengaruh BBLR dan pemberian ASI eksklusif terhadap perubahan status stunting pada balita di kota dan kabupaten Tangerang provinsi Banten. Prosoding Seminar Nasional. 2011.

10. Kusharisupeni. Peran status kelahiran terhadap stunting pada bayi: sebuah studi prospektif. Jurnal Kedokteran Trisakti. 2002; 23: 73-80.

11. Faiza R, Elnovriza D, Syafianti. Faktor risiko kejadian gizi buruk pada anak (12-59 bulan) di wilayah kerja Puskesmas Andalas Kecamatan Padang Timur Kota Padang tahun 2007. Media Gizi dan Keluarga. 2007; 31: 80-6.

12. Rahayu LS. Associated of height of parents with changes of stunting status from 6-12 months to 3-4 years [Tesis]. Yogyakarta: Universitas Gajah Mada; 2011.

13. Arnelia, dkk. Besaran Defisit Zat Gizi Makro dan Mikro pada Anak Baduta dengan Masalah Kurus di Pedesaan dan Perkotaan di Indonesia. Puslitbang Gizi dan Makanan. Bogor. 2008.

14. Kementerian Kesehatan RI. Panduan pelayanan kesehatan bayi baru lahir berbasis perlindungan anak. 2010. hlm 19, 27.

15. American academy of pediatrics. Committe on nutrition: breastfeeding and the use of human milk. Pediatrics. 2005; 115: 496.

16. Poskitt EME, Morgan JB. Infancy, childhood and adolescene.In: Geissler CA, editor. Human Nutrition. 11th ed. China: Elsevier Churchill Livingstone. 2005. p. 289-91.

17. Azwar S. Sikap manusia teori dan pengukurannya. Yogyakarta: Pustaka pelajar; 2008. hlm 156.
18. M. Sopiyudin Dahlan. Statistik untuk kedokteran kesehatan. Ed 4. Jakarta: Salemba Medika. 2009. hlm 21, 141-144.

19. Kiely JL, Yu S, Rowley DL. Low Birth weight and intrauterine growth retardation. CDC public health surveillance for women, infants and children. 2013.

20. Adel El, Ibrahim Betilmal, Salah MM, Abdel MA, et al. Risk factors for stunting among under-fives in Libya. Public Health Nutrition: 2004;12(8).

21. Adair LS, Guilkey DK. Age spesific determinants of stunting in Filipino children. The Journal of Nutrition. 1997; 127(2).

22. Simondon KB, Costes R, Delaunay V, Diallo A, Simondon F. Children's height, health and appetite influence mothers weaning decisions in rural Senegal. International journal of epidemiology. 2001; 30: 476-48.

23. Asdani P. Faktor-faktor yang Mempengaruhi Ibu dalam Pemberian MP-ASI Dini di Kecamatan Pandan Kabupaten Tapanuli Tengah Tahun 2007. Medan: Universitas Sumatera Utara; 2008.

24. Padmadas SS, Hutter I, Willekens F. Weaning initiation patterns and subsequent linier growth progression among children aged 2-4 years in India. International Journal of Epidemiology 2002; 31: 855-63.

25. Dewey KG, Mayers DR. Early child growth: how do nutrition and infection interact?. Maternal and child nutrition. 2011; 7(suppl 3): 129-42.

26. Caulfield LE, Richard SA, Rivera JA, Musgrove P, Black RE. Stunting, wasting and micronutrient deficiency disorders. In: Jamison DT, Breman JG, Measham AR, Alleyne G, Cleason M, Evans DB, et al, editors. Disease control priorities in developing countries. 2nd ed. New York: The World Bank and Oxford University Press; 2006. p. 551-67

27. Astari LD, Nasoetion A, Dwiriani CM. Hubungan konsumsi ASI dan MP-ASI serta kejadian stunting anak usia 6-12 bulan di Kabupaten Bogor. Media Gizi dan Keluarga. 2006; 30: 15-23.

28. Whitney E, Rolfes SR. Understanding nutrition. 11th ed. USA: Thomson Wadsworth; 2008. p. 5257, 550-6

29. Trahms CM, McKean KN. Nutrition during infancy. In: Mahan LK, EscottStump S, editors. Krause`s food, nutrition, and diet therapy. $11^{\text {th }}$ ed. USA : Saunders. 2004. p. 206-8, 215, 224, 232, 384.

30. Barrens H, Simmala C, Odermatt $P$, Thaybouavone T, Valle J, Martinez Ussel B et al. Postpartum traditions and nutrition practices among urban Lao women and their infants in Vientiane, Lao PDR. Eur J Clin Nutr 2007; 63(3):323-31. 